\title{
GLOBE-PRESERVING SURGERY FOR TREATMENT OF ADVANCED EYELID CARCINOMA INFILTRATING ANTERIOR PERIORBITAL FAT TISSUE: CASE REPORT
}

\author{
Nina Vujošević1,3, Predrag Kovačević2,4
}

\begin{abstract}
Basal cell carcinoma (BCC) is the commonest eyelid malignancy followed by squamous cell carcinoma and other rare tumors. Often, periocular skin BCC attacks deeply into tissues and infiltrates the orbit. Generally, periorbital malignancies behave more aggressively than malignancies at other cutaneous sites. In case of orbital infiltration, the surgical management remains challenging.

A 64-year-old male patient with basal cell skin cancer of periorbital skin invading the orbit is presented. The patient refused orbital exenteration. A globe-preserving tumor excision with primary reconstruction was performed. During a two-year follow up there was no sign of tumor relapse, but the orbital movements were slightly reduced.

Although in most cases of orbital invasion the exenteration remains the treatment of choice, a globe-sparing treatment may be appropriate in selected patients. The gold standard of treatment is a wide surgical excision which provides the lowest recurrence rate. The primary reconstruction yields acceptable aesthetic and functional results.
\end{abstract}

Acta Medica Medianae 2020;59(1):83-89.

Key words: basal cell carcinoma, exenteration, globe-sparing excision

\footnotetext{
${ }^{1}$ University of Niš, Faculty of Medicine, PhD student, Niš, Serbia

2University of Niš, Faculty of Medicine, Niš, Serbia

${ }^{3}$ Clinic of Ophthalmology, Clinical Center Niš, Niš, Serbia

${ }^{4}$ Clinic for Plastic and Reconstructive Surgery, Clinical Center Niš, Niš, Serbia
}

Contact: Nina Vujošević

48 Dr Zoran Djindjić Blvd., 18000 Niš, Serbia

E-mail: lazic.nina88@gmail.com

\section{Introduction}

The periocular/periorbital skin involves the skin of the upper lid, lower lid, lid margins, medial canthus with lacrimal system, and lateral canthus. In that region, different benign and malignant neoplasms occur. Periocular malignancies show aggressive behavior, and the treatment and repair of defect are challenging compared to tumors at other cutaneous sites. Five to ten percent of cutaneous malignancies occur in the periorbital region, with basal cell carcinoma (BCC) reported as the commonest periocular tumor (up to $90 \%$ ) $(1-3)$, followed by squamous cell carcinoma, sebaceous gland carcinoma, cutaneous melanoma, Merkel cell carci- noma, microcystic adnexal carcinoma, and other malignant neoplasms. General statement is that early diagnosis and proper radical surgery obtains best chance for eradication, while uncontrolled tumor growth could invade the anatomical structures in their proximity such as the orbit. Orbital invasion by periorbital skin BCC is reported in $0.8-5.5 \%$ cases $(1,4-6)$, but local invasion can rarely spread to intracranial structures and be the cause of death (3).

Orbital invasion is more often seen in male gender, in cases of multiple recurrences, large tumors, aggressive histologic subtypes, perineural invasion, medial canthal location and older patients $(2,5)$. The most common primary location for BCCs inclined to invasion is the medial canthal region (53.6-56.2\%), followed by the lower eyelid (20.3$35.7 \%)$, the upper eyelid (4.7-7.1\%) and the lateral canthus $(3.6-18.7 \%)(2,4,5)$. Tumor can infiltrate the periosteum of the orbital wall especially in medial and lateral canthus where the skin is in close proximity to periosteum (7).

Aggressive subtypes of BCC (infiltrative, morpheaform/sclerosing and basosquamous) make more than $80 \%$ of cases of orbital invasion, with the infiltrative one being the most commonly reported subtype encountered $(51.6-78.6 \%)(1,8)$.

Orbital invasion may be entirely asymptomatic. It means that the diagnosis requires a high index of suspicion $(3,9)$.

Signs of orbital invasion include an orbital mass fixed to bone, strabismus, limitation of ocular 
motility, and globe displacement or destruction. Recurrent tumors are in advanced stages, graded by TMN staging system, suspicious at huge subclinical extension, leaving larger operative defects. It is important to obtain tumor excision with margin control (2).

The delicate anatomy and specific functional rule of the periocular zone requires adequate surgical skills and care related to radicality (free margins have to be respected), meeting also aesthetic demands (10).

The management of periocular BCC with orbital invasion represents challenges and often requires an oncological board decision. The board includes plastic surgeon, ophthalmologist and radiation oncologist. Treatment should be individualized, patient-related, taking into account different factors such as general health of the patient, patient's wish, as well as the tumor extent and visual function. Exenteration alone or with radiotherapy is the treatment of choice for patients with bulbar or extensive orbital invasion with an estimated recurrence rate of up to $28.5 \%(5,11,12)$.

Total orbital exenteration is a surgical complete removal of the globe and all orbital contents including periorbita (periosteum). Subtotal orbital exenteration is classified as the removal of the globe and partial removal of orbital tissues (13).

In selected cases, globe-sparing local tumor excision alone or with radiotherapy is an alternative option in surgical treatment (5). Globe-sparing excision could be performed in patients with anterior orbital involvement only, in patients with a single eye, or when a patient declines exenteration $(2,14)$.

Margin control should be strongly considered for cases treated with globe sparing local excision. The control of choice for resection borders is paraffin-embedded tissue in any case of BCC with orbital invasion. High-quality tissue samples are illustrative in cases involving orbital fat (1).

Complications of globe-preserving tumor excision are usually late functional disturbance of re- stricted ocular motility, epiphora secondary to nasolacrimal obstruction and abnormal lid position (1).

The close follow-up imaging should be performed in all patients, (regular MRI is preferable). It can detect early posterior recurrences, which may sometimes be hidden and undiagnosed due to the presence of scar tissue (2).

\section{Case report}

A 64-year-old man was referred to the Clinic for exulcerated periorbital skin tumor affecting the lateral third of both eyelids and lateral canthal region. Tumor was infiltrating the orbit, being fixed to the lateral orbital wall periosteum. The tumor had appeared four years before, but the patient was not referred to any surgeon till that moment. The oculomotor functions and visual acuity were in reference ranges. Computed tomography scans presented a tumor mass infiltrating extraconal orbital fat and lateral orbital wall periosteum. Multidisciplinary oncology board strongly suggested an orbital exenteration, but the patient refused to underwent this type of surgery. A conservative approach was discussed with the patient and a globe-sparing surgery was advocated. The patient was informed about the risks of this treatment. After tumor excision affecting the lateral third of eyelids and lateral cantus, the periorbital fat and broad area of lateral orbital wall periosteum was removed.

The defect was reconstructed primarily. A partial thickness skin graft was applied for conjunctival reconstruction, and a transposition flap was used for palpebral reconstruction. Donor region was closed using a tension free technique. After the removal of stiches, an acceptable aesthetic result was obtained. Pathological analysis indicated the diagnosis of BCC and clear resection margins on all samples. During a two-year follow-up, there was neither tumor recurrence nor visual impairment.

Results are presented in figures 1-7.

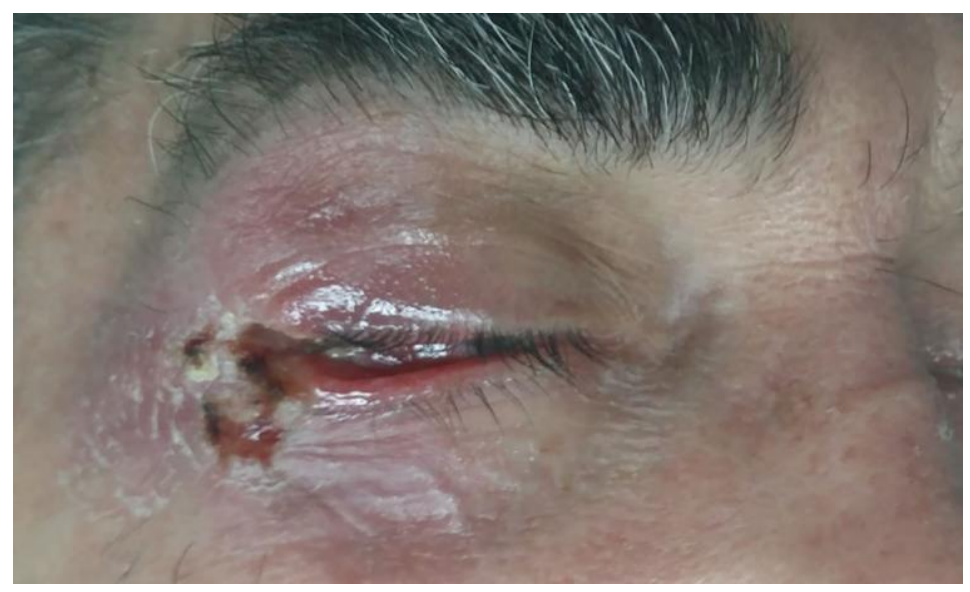

Figure 1. Right lateral canthal infiltrative basal cell carcinoma with lateral orbital invasion 


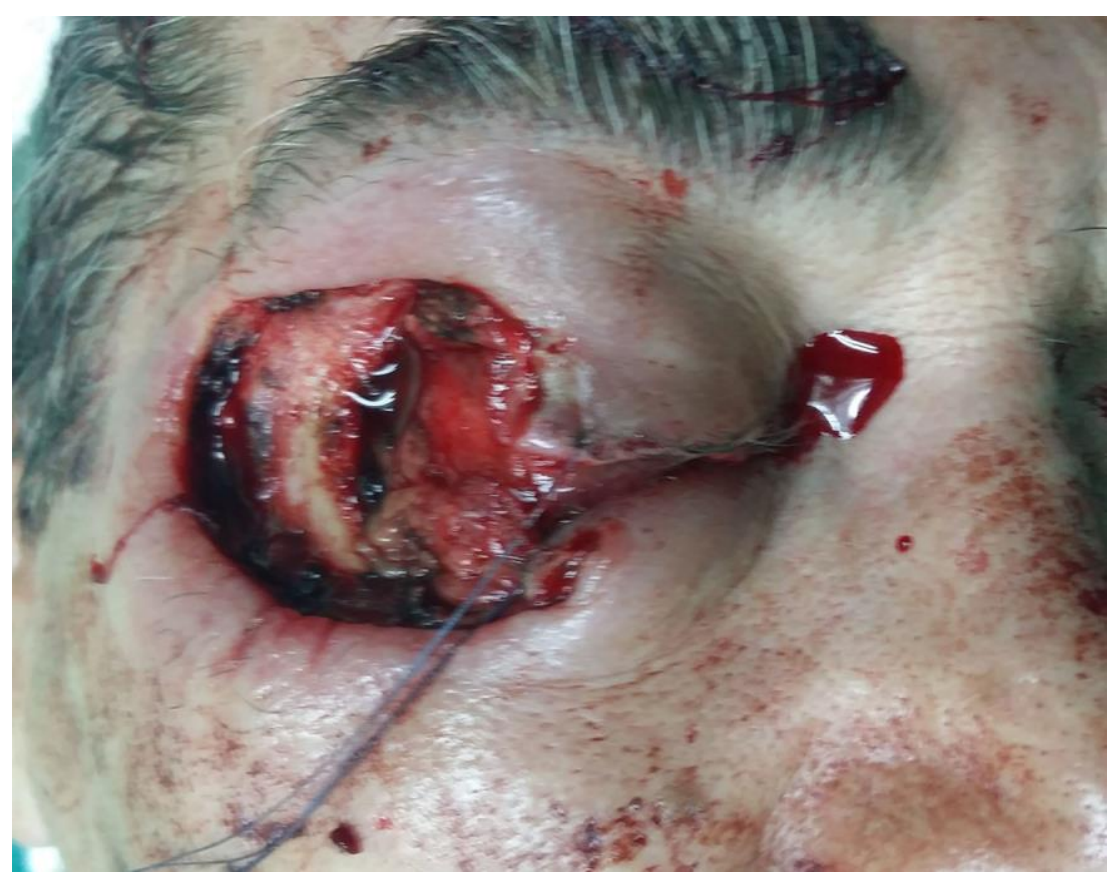

Figure 2. A globe-sparing resection of the lateral canthus and lateral orbital rim was performed

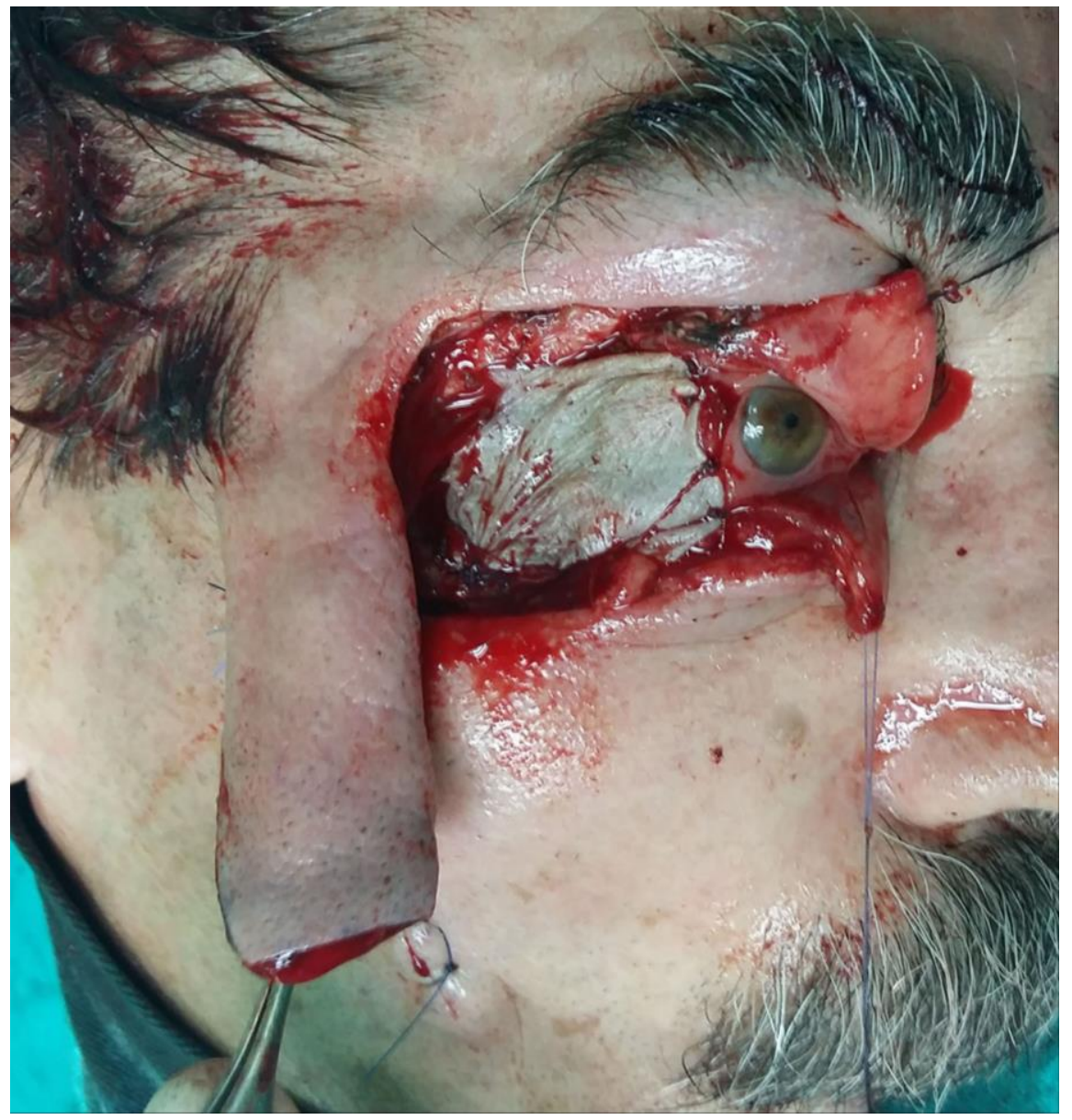

Figure 3. Bulbar conjunctiva was reconstructed with buccal mucosal graft 


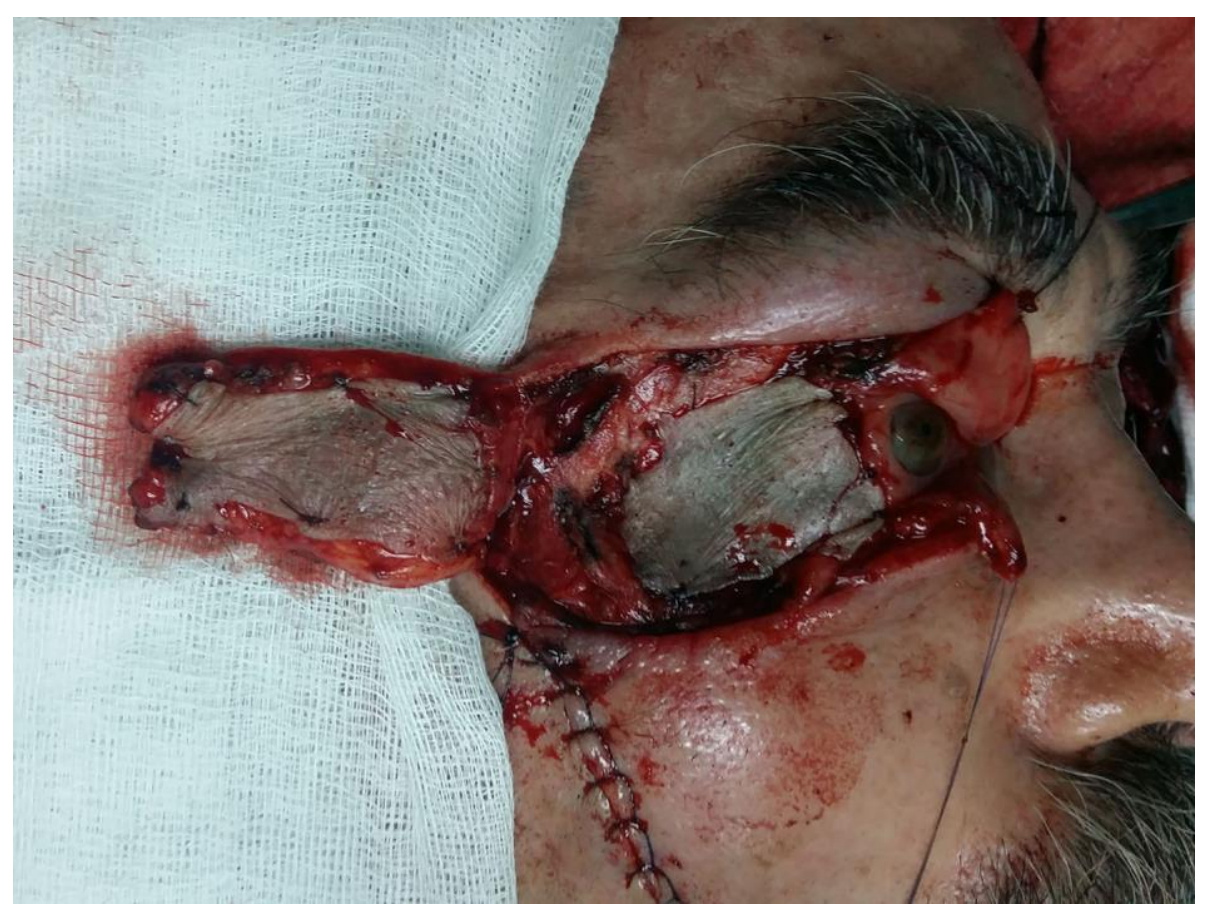

Figure 4. Transposition cheek flap was used as a skin graft for palpebral conjunctival reconstruction

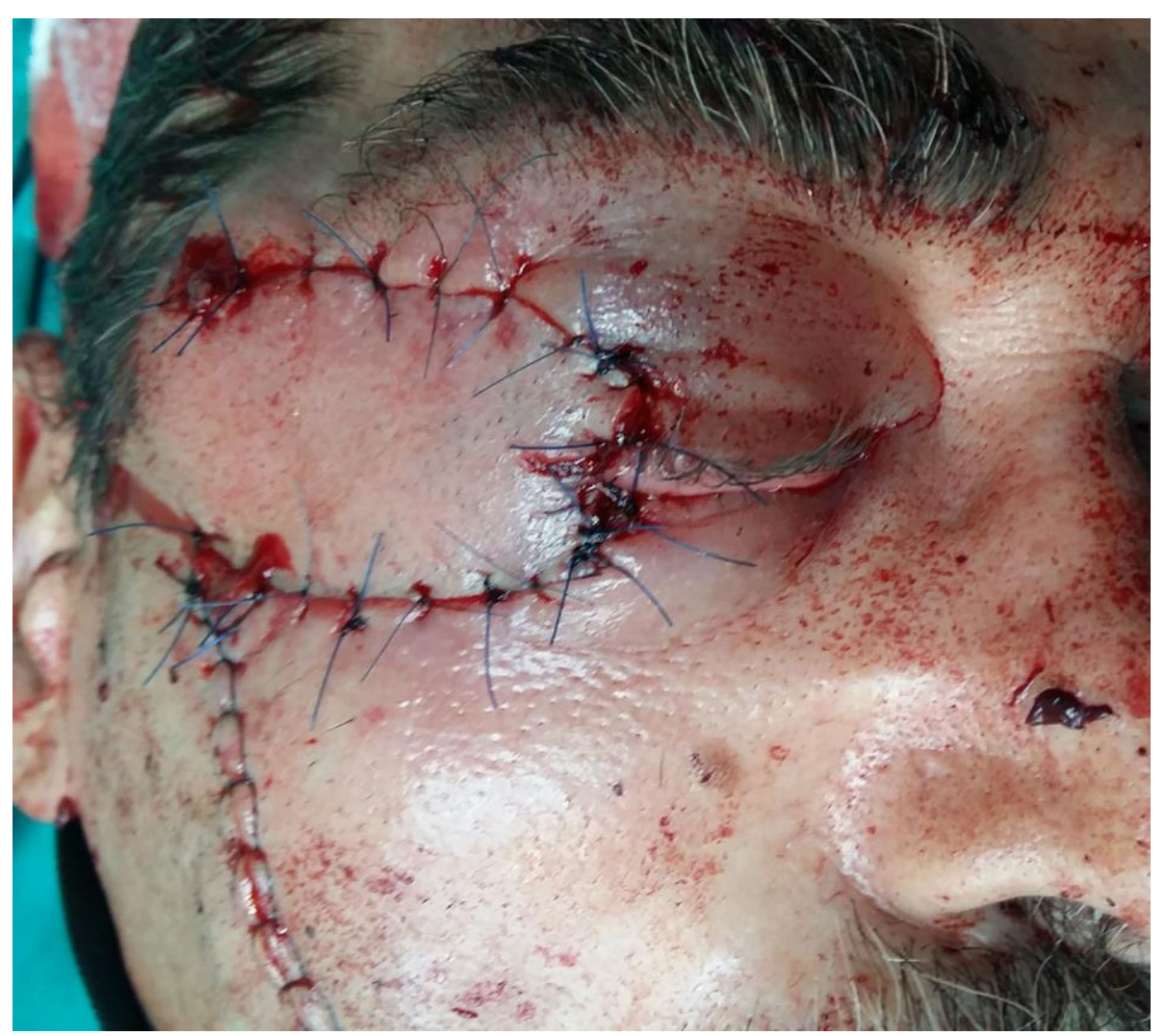

Figure 5. End of surgery 


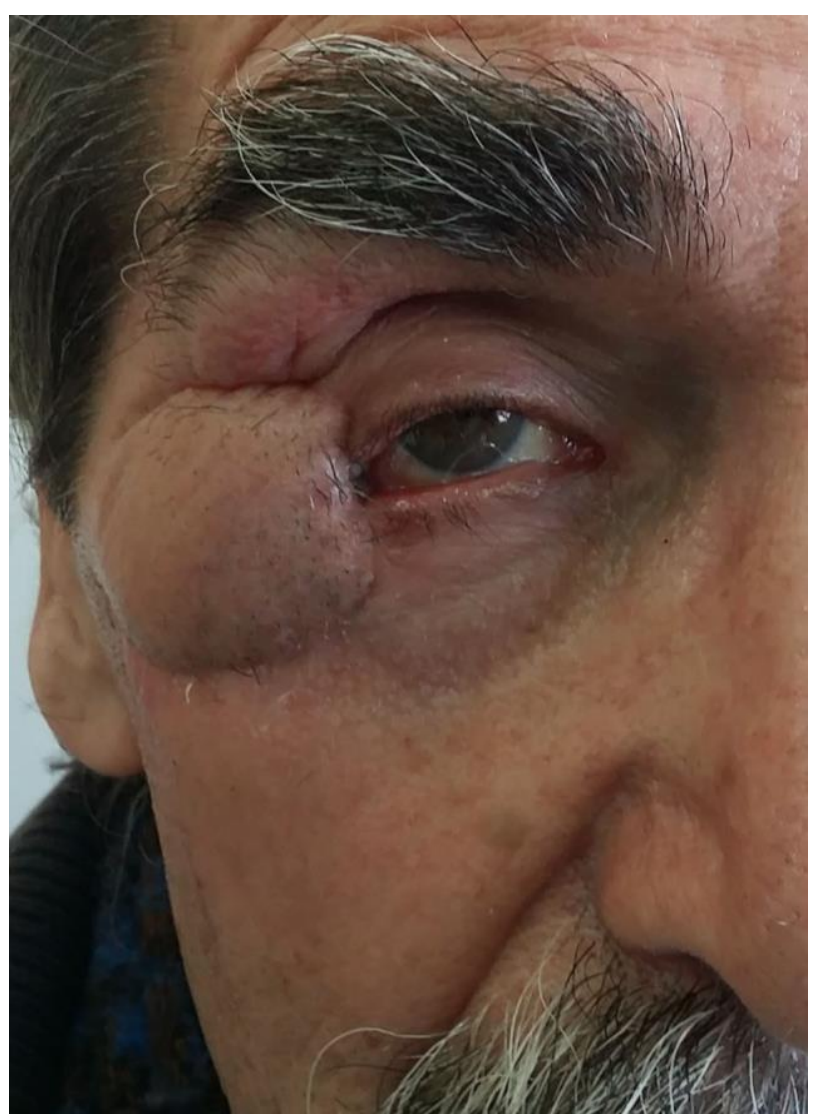

Figure 6. Postoperative results 24 months after surgery -open eyes-

\section{Discussion}

The above presented patient represents a periorbital skin BCC spread into the anterior orbit with peribulbar fat and periorbita invasion. The patient was managed using surgical techniques of globesparing (preserving) surgical tumor excision. There is only scant literature on the topic (2). BCC is typically a slow-growing malignancy demonstrating little local invasion; however, BCC arising in the periocular region has been associated with a more aggressive phenotype (11).

Local invasion into orbital tissues is associated with a worse prognosis (3).

Many risk factors have been identified for orbital invasion by periocular BCC (11).

Because our patients refused exenteration, the only possible surgical technique was globe-sparing surgery. The signs suggestive of orbital invasion including restricted ocular motility, malposed eye globe, palpable mass fixed to orbital periosteum were present.

A higher incidence of orbital invasion by periocular BCC in male patients is well known and reported in about $77 \%$ of patients (5).

This could be discussed according to higher aggressiveness of BCC in males and because male patients apply for medical treatment in more advanced tumor stages than females (11).

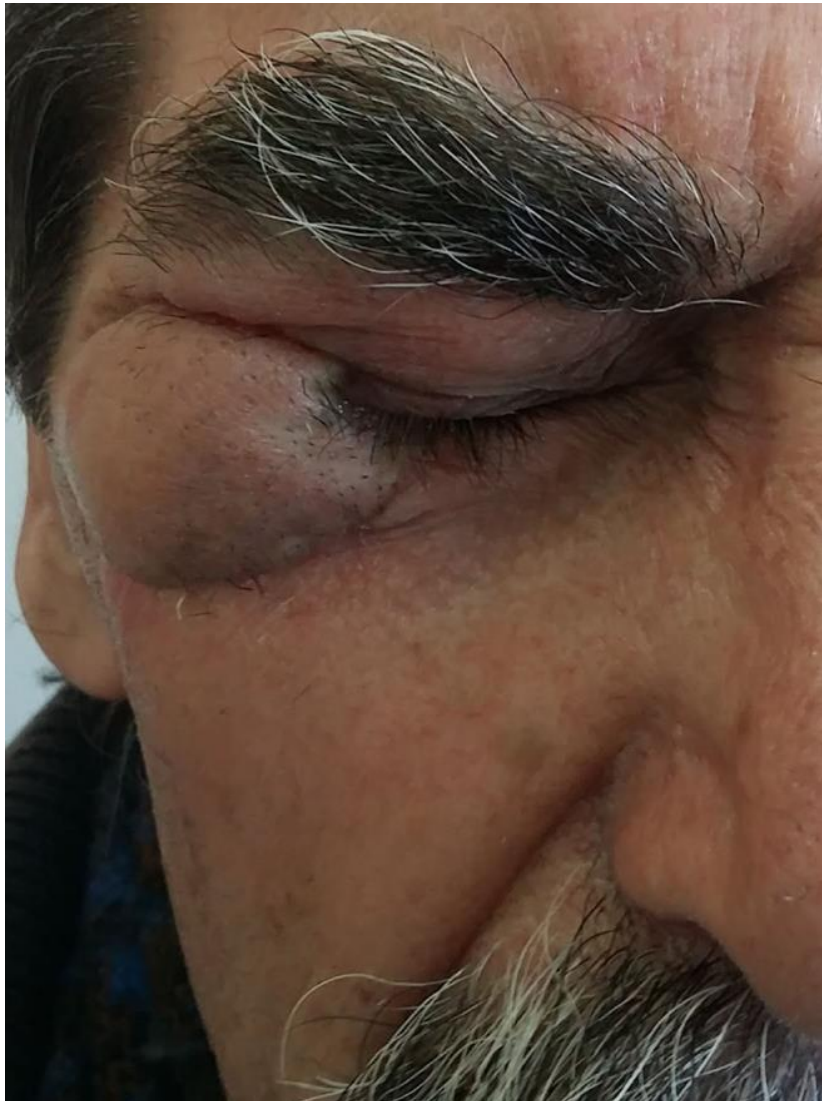

Figure 7. Postoperative results 24 months after surgery -closed eyes-

Periorbital BCC is commonly diagnosed from $5^{\text {th }}$ to $7^{\text {th }}$ decade of life, but orbital invasion is mostly registered in patients in their late sixties (68-70 years) $(2,5)$.

In 71.4-84.4 \% of patients with orbital invasion by $\mathrm{BCC}$, the tumor is recurrent or previously incompletely excised. The remainder are advanced primary tumors found in the first visit (7).

An alternative approach in selected cases with early anterior orbital invasion is conservative globesparing (non-exenterating) excision with or without adjunctive radiotherapy $(2,15)$.

Although there is significant literature concerning orbital invasion by eyelid malignancies, conservative surgery and its outcomes are not welldescribed. In patients after globe sparing surgery, an annual postoperative MRI for at least 5 years is mandatory as part of the follow-up (1).

We report a patient with histologically confirmed, anterior orbital invasion by BCC who was managed with conservative (non-exenterating) surgery. Indication for surgery, clinical presentation, surgical technique, and outcome are discussed.

Some authors report the recurrence rate after globe sparing surgery for medial canthal BCC with orbital invasion about $5 \%$ during a mean follow-up of 3.2 years (1). There is no published data regarding recurrence rate with longer follow-up, but it is likely to be higher. 
The decision of radical (exenteration) or conservative- globe sparing surgery in case of orbital invasion in periorbital BCC must be made after detailed discussion with the patient. The same principle applies to lateral canthal BCC with limited anterior orbital invasion and the globe-sparing approach may be considered. This type of surgery brings the risk of postoperative complications and possible revision procedures. When the tumor is highly aggressive and has higher risk of recurrence, or perineural invasion, exenteration may be suggested as the preferred treatment choice $(1,10)$.

\section{Conclusion}

Orbital invasion by periocular BCC is rare, but the treatment is difficult and the complication rate is high. Radical tumor removal must be confirmed by paraffin margin control. Besides orbital exenteration in selected cases, conservative surgery with globe sparing excision is one of the recommended approaches. Globe-sparing surgical excision with mandatory yearly performed MR imaging as a regular follow-up may be appropriate in case of anterior orbital involvement only, in patients with a single eye or with poor vision in the opposite eye. Also, globe-sparing procedure could be performed in cases when patient refuses exenteration.

In case of orbital infiltration by periorbital skin $\mathrm{BCC}$, the orbital extenteration remains the gold standard, but globe-sparing surgery can be considered in select cases.

\section{References}

1. Madge SN, Khine AA, Thaller VT, Davis G, Malhotra R, McNab $A$, et al. Globe-sparing surgery for medial canthal Basal cell carcinoma with anterior orbital invasion. Ophthalmology 2010; 117(11):2222-8. [CrossRef] [PubMed]

2. Leibovitch I, McNab A, Sullivan TJ, Davis G, Selva D. Orbital invasion by periocular basal cell carcinoma. Ophthalmology 2005; 112(4):717-23. [CrossRef] [PubMed]

3. Prabhakaran VC, Gupta A, Huilgol SC, Selva D. Basal cell carcinoma of the eyelids. Compr Ophthalmol Update 2007; 8(1):1-14. [PubMed]

4. Wong VA, Marshall JA, Whitehead KJ, Williamson RM, Sullivan TJ. Management of periocular basal cell carcinoma with modified en face frozen section controlled excision. Ophthalmic Plast Reconstr Surg 2002; 18(6), 430-5. [CrossRef] [PubMed]

5. Iuliano A, Strianese D, Uccello G, Diplomatico A, Tebaldi S, Bonavolonta G. Risk factors for orbital exenteration in periocular Basal cell carcinoma. Am J Ophthalmol 2012; 153(2):238-41. [CrossRef] [PubMed]

6. Malhotra R, Huilgol SC, Huynh NT, Selva D. The Australian Mohs database, part I: periocular basal cell carcinoma experience over 7 years. Ophthalmology 2004; 111(4):624-30. [CrossRef] [PubMed]

7. Walling HW, Fosko SW, Geraminejad PA, Whitaker DC, Arpey CJ. Aggressive basal cell carcinoma: presentation, pathogenesis, and management. Cancer Metastasis Rev 2004; 23(3-4), 389-402. [CrossRef] [PubMed]
8. Paavilainen V, Aaltonen M, Tuominen J, Saari KM. Histological characteristics of basal cell carcinoma of the eyelid. Ophthalmic Res 2007; 39(1):45-8. [CrossRef] [PubMed]

9. Selva D, Hale L, Bouskill K, Huilgol SC. Recurrent morphoeic basal cell carcinoma at the lateral canthus with orbitocranial invasion. Australas J Dermatol 2003; 44(2):126-8. [CrossRef] [PubMed]

10. Slutsky JB, Jones EC. Periocular cutaneous malignancies: a review of the literature. Dermatol Surg 2012; 38(4):552-69. [CrossRef] [PubMed]

11. Meads SB, Greenway HT. Basal cell carcinoma associated with orbital invasion: clinical features and treatment options. Dermatol Surg 2006; 32(3):442-6. [CrossRef] [PubMed]

12. Williams LS, Mancuso AA, Mendenhall WM. Perineural spread of cutaneous squamous and basal cell carcinoma: CT and MR detection and its impact on patient management and prognosis. Int J Radiat Oncol Biol Phys 2001; 49(4):1061-9. [CrossRef] [PubMed]

13. Ben Simon GJ, Schwarcz RM, Douglas R, Fiaschetti D, McCann JD, Goldberg RA. Orbital exenteration: one size does not fit all. Am J Ophthalmol 2005; 139 (1): 11-17. [CrossRef] [PubMed]

14. Satchi K, Mcnab AA. Orbital spread of eyelid and periocular cutaneous cancer. Int Ophthalmol Clin 2009; 49(4):223-36. [CrossRef] [PubMed]

15. Sun MT, Wu A, Figueirae $E$, Huilgol $S$, Selva $D$. Management of periorbital basal cell carcinoma with orbital invasion. Future Oncol 2015; 11(22):3003-10. [CrossRef] [PubMed] 


\title{
HIRURŠKO LEČENJE UZNAPREDOVALOG KARCINOMA KAPKA KOJI INFILTRIRA PREDNJE PERIBULBARNO MASNO TKIVO UZ OČUVANJE OČNE JABUČICE - PRIKAZ SLUČAJA
}

\author{
Nina Vujošević1,3, Predrag Kovačević2,4 \\ ${ }^{1}$ Univerzitet u Nišu, Medicinski fakultet, student doktorskih studija, Niš, Srbija \\ 2Univerzitet u Nišu, Medicinski fakultet, Nišs, Srbija \\ ${ }^{3}$ Klinika za oftalmologiju, Klinički centar Niš, Niš, Srbija \\ ${ }^{4}$ Klinika za plastičnu i rekonstruktivnu hirurgiju, Klinički centar Niš, Niš, Srbija
}

Kontakt: Nina Vujošević

Bul. dr Zorana Đinđića 48, 18000 Niš, Srbija

E-mail: lazic.nina88@gmail.com

Karcinom bazalnih ćelija (KBĆ) najčešči je malignitet kapka, koji prate karcinom skvamoznih ćelija i drugi retki tumori. KBĆ periokularne kože često se širi u dublje slojeve i infiltrira orbitu. Periorbitalni maligniteti uglavnom se ponašaju mnogo agresivnije nego maligniteti na ostalim mestima na koži. U slučaju infiltracije orbite, hiruško lečenje ostaje izazov.

Prikazan je šezdesetčetvorogodišnji bolesnik muškog pola sa karcinomom bazalnih ćelija kože periorbite koji invadira u orbitu. Bolesnik je odbio egzenteraciju orbite. Izvedena je ekscizija tumora sa primarnom rekonstrukcijom i očuvanjem očne jabučice. Za vreme dvogodišnjeg praćenja, nije bilo znakova recidiva tumora, ali su pokreti očne jabučice bili blago redukovani.

Iako u većini slučajeva orbitalne invazije egzenteracija ostaje izborna metoda lečenja, poštedna operacija očne jabučice može biti odgovarajuća kod određenih bolesnika. Zlatni standard u lečenju predstavlja ekstenzivna hirurgija, kod koje se očekuje najniža stopa recidiva. Primarna rekonstrukcija omogućava zadovoljavajuće estetske i funkcionalne rezultate.

Acta Medica Medianae 2020;59(1):83-89. jabučice

Ključne reči: karcinom bazalnih ćelija, egzenteracija, poštedna ekscizija očne 